\title{
Effect of Alternate Furrow Irrigation with Different Irrigation Intervals on Tomato (Lycopersicon E.) Yield and Water Use Efficiency
}

\author{
Jemal Nur*, Lalisa Ofgea \\ Oromia Agricultural Research Institute, Fedis Agricultural Research Centre, Harar, Ethiopia
}

Email address:

jeminur@gmail.com (J. Nur)

${ }^{*}$ Corresponding author

To cite this article:

Jemal Nur, Lalisa Ofgea. Effect of Alternate Furrow Irrigation with Different Irrigation Intervals on Tomato (Lycopersicon E.) Yield and Water Use Efficiency. Journal of Water Resources and Ocean Science. Vol. 10, No. 5, 2021, pp. 115-122. doi: 10.11648/j.wros.20211005.13

Received: August 24, 2021; Accepted: September 22, 2021; Published: September 27, 2021

\begin{abstract}
Experiment was conducted at Eastern Ethiopia of Harari Regional State of Erer Woldiya district, on farmers' field for two years. The purpose of this study was to evaluate the effect of AFI and EFI with different irrigation intervals on growth component, yield and water use efficiency of tomato for two years 2018 and 2019. Accordingly plant height and NFPP were significantly $(\mathrm{P}<0.05)$ influenced by (IMs), whereas (IIs) had highly significant $(\mathrm{P}<0.01)$ effect on plant height and NFPP at both planting season. Total tomato yield was significantly influenced $(\mathrm{P}<0.05)$ by furrow IMs, but application frequency had highly significant $(\mathrm{p}<0.01)$. Water saved from treatment combination of AFI with 4,6 and 8 days water IIs were $16 \%, 44 \%$ and $58 \%$ of total volume of irrigation water applied. Whereas water saved from EFI with 6 and 8 days of application was $33.3 \%$ and $50 \%$ respectively. AFI with 4 day water application shows little yield reduction as $4.97 \%$, as compared with no stressed treatment; EFI with the same water application frequency). But AFI with 4 day II was saves $16 \%$ water from gross water applied for no stressed treatment EFI with 4 day. Treatment with 6 day II of AFI and, EFI were indicated that significant yield reduction as $15.74 \%$ and $14.61 \%$ respectively. But total amount of gross volume of irrigation water saved as 44 and $33.3 \%$ for AFI and EFI of the same II treatment. Crop water productivity (CWUE, IWUE and EWP) were highly significantly $(\mathrm{P}<0.01)$ influenced by both IMs and IIs. The result clearly confirms that, AFI had beneficial advantage over EFI on water saving and, the same consequent is happened for irrigation interval i.e. increasing interval from 4 day followed by 6 to 8 days increases water use efficiency of crop. Hence the result indicates that interaction effect of both factors (IMs and IIs) could save significant amount of irrigation water.
\end{abstract}

Keywords: Irrigation Methods, Irrigation Intervals, Tomato, Growth, Yield Parameters, Water Productivity

\section{Introduction}

Agriculture is the largest freshwater user on the planet, consuming more than two thirds of total withdrawals [1]. In many parts of the world, irrigation water has been overexploited and over-used, and freshwater shortage is becoming critical in the arid and semiarid areas of the world $[2,3]$. About $93 \%$ of the available fresh water resources are currently utilized in the agricultural sector [4]. The increasing population has resulted in demand for more food and fiber, which is met through increasing irrigated agriculture. It is critical therefore that management and utilization of available water resources is improved at all scales; from catchment, to irrigated district, to farm and field scale.

Traditional surface irrigation methods (basin, border and furrow) are widely used to irrigate crops. Those are however inefficient irrigation methods and considered one of the main causes of waterlogging and salinization [5]. The reason why small holders farmers practiced traditional, ones are affordability and capacity on the use of modern, high-tech and efficient micro irrigation methods (drip, bubbler, sprinkler etc.) which are advocated worldwide. Though those modern and efficient irrigations are available in developing countries like Ethiopia these methods have not yet been 
widely adopted by farming communities.

Therefore need more efficient irrigation methods that are economical, easy to install and operate, and which are readily acceptable to the farming communities are mandatory for this reason, introducing every furrow irrigation method (EFI) to be transformed into alternate furrow irrigation (AFI) then it might be readily accepted by farmers. However, before introducing and advocating this method to local farmers for adoption, the method needs to be evaluated under soil and climatic conditions for representative areas being targeted. According to different finding AFI method is basically the same as EFI, except that instead of irrigating every furrow, irrigation water is applied to alternate furrows, while the inbetween furrows remain dry [6]. This means each ridge receives water from only one side, and the side receiving irrigation water could be changed with each irrigation if the field is set up to facilitate this change. Irrigating just one side of the ridge means there is significant potential to save irrigation water compared to EFI, with some yield reduction [7]. Moreover, [8,9] reported (AFI) is considered to be one of the most effective tools to minimize water application and irrigation costs and produce a higher crop yield. The AFI method is a way to save irrigation water, improve irrigation efficiency, and increase corn yield.

Eastern part of Ethiopia (Harari Region), ranked as the last among region in terms of surface and ground water potential due to the topography and hydro-geological condition, [10]. The source of water for domestic and agricultural use especially for irrigation vegetable production during dry season is groundwater, which is availed by constructing traditionally hand-dug wells. Farmers fit their wells with pressurized engine pumps (centrifugal pump) exploit the water for irrigating their farm. Even though irrigation practice virtuous, they don't have knowledge about irrigation management or water productivity. Farmers consider only water is applied to maximize crop yield (maximizing production per unit of land). So to resolve this ineffective irrigation practice and, to enhance best water saving, as compared to this situation they have to adopt optimum water productivity methods through practicing and promoting water-use efficiency and productivity techniques to optimize yield and cost incurred, like alternate and interval of irrigation as alternative irrigation to achieve on-farm water management and to get better yield with this scarce resource and minimize other variable cost. Generally this experiment aimed to evaluate the effect of AFI and EFI with different irrigation intervals on yield and water use efficiency.

\section{Materials and Methods}

The study was conducted in Harari Regional State of Erer Woldiya district in Erer Dodota kebele. Representative site was selected purposively based on availability resource required and willingness the farmer to brought the experimental land, as well as access for field monitoring and follow up. Accordingly the sites was situated at $42^{\circ} 11^{\prime} 00^{\prime \prime}$ to $42^{\circ} 15^{\prime} 30^{\prime \prime}$ and $9^{\circ} 15^{\prime} 22^{\prime \prime}$ to $9^{\circ} 19^{\prime} 35^{\prime \prime}$ East latitude and North longitude respectively. The site receives a mean annual rainfall of $400 \mathrm{~mm}$. It has erratic and uneven in distribution, with mean minimum and maximum temperatures of $25^{\circ} \mathrm{C}$ and $35^{\circ} \mathrm{C}$, respectively. The major soil types which occur in lowlands of the Erer Woldiya districts are Luvisols (Sandy soil) $90 \%$ and nitisols (clay) $10 \%$ [11]. The soil in the experimental site Erer dodota, being sandy loam.

\subsection{Treatments and Experimental Design}

The experiment has two factors, factorial design arranged in randomized complete block design (RCBD) with three replications. The treatments considered for the experiment were namely two furrow irrigation methods AFI (Alternative furrow irrigation and EFI (every furrow irrigation) and three irrigation interval or days $(4,6$, and 8 , interval for successive /next irrigation), hence there are six treatment combinations (Table 1).

Table 1. Treatment description.

\begin{tabular}{lll}
\hline S. № & Treatment & Treatment Combination \\
\hline 1 & $\mathrm{AFI}_{8}$ & Alternative Furrow Irrigation (AFI) with 8 II \\
2 & $\mathrm{AFI}_{6}$ & Alternative Furrow Irrigation (AFI) with 6 II \\
3 & $\mathrm{AFI}_{4}$ & Alternative Furrow Irrigation (AFI) with 4 II \\
4 & $\mathrm{EFI}_{8}$ & Every Furrow Irrigation (EFI) with 8 II \\
5 & $\mathrm{EFI}_{6}$ & Every Furrow Irrigation (EFI) with 6 II \\
6 & $\mathrm{EFI}_{4}$ & Every Furrow Irrigation (EFI) with 4 II \\
\hline
\end{tabular}

Note: II = Irrigation interval/day.

The experiment was conducted on individual plot size of $3.5 \mathrm{~m} \times 5 \mathrm{~m}\left(15 \mathrm{~m}^{2}\right)$ with 18 number of such plot. The spacing between the blocks and plots were kept as $2 \mathrm{~m}$ and 1 $\mathrm{m}$ respectively. Each plot had 5 furrows and 4 planting ridges (rows) with $0.8 \mathrm{~m}$ and $0.3 \mathrm{~m}$ furrow and between plants spacing respectively. A test crop tomato (Melka shola variety) seed of (cultivar: $O P V$ ) was used which, was adapted in study area with a purity test of $98 \%$, and having germination percentage of $85 \%$ collected from Fedis Agricultural Research Center (FARC) of Horticulture Department. Five weeks after germination seedlings were transplanted on experimental plots.

A common recommended fertilizer rate was applied manually in the experimental plots. All plots received the same amounts of fertilizer consisted of $150 \mathrm{~kg} \mathrm{ha}^{-1}$ of urea and $100 \mathrm{~kg} \mathrm{ha}^{-1}$ of $\mathrm{P}_{2} \mathrm{O}_{5}$ (DAP). The irrigation water used in the study was obtained from a well. Crop water requirements was estimated using the CROPWAT computer software program using and climatic, soil and crop data as input.

\subsection{Soil Texture and Water Holding Analysis}

Soil samples from the experimental plots were taken to analyze bulk density, texture, moisture content at filed capacity and permanent wilting point from the field at three points along the diagonal of the experimental plot at two depth 0-20 $\mathrm{cm}$ and $20-40 \mathrm{~cm}$.

Soil texture, organic matter and $\mathrm{pH}$ measurement: The particle size distribution in the soil profile was done using hydrometric method following the procedure outlined in 
[12]. For this purpose disturbed soil samples from the 3 locations on the experimental field was collected from a depth of $0-20 \mathrm{~cm}$ and $20-40 \mathrm{~cm}$ with the help of soil auger and composite samples were prepared. Organic carbon (\%) was determined by potassium dichromate wet combustion producer [13] Organic matter was obtained by multiplying organic carbon by conversion factor of 1.724 . The $\mathrm{pH}$ of the soil in experimental site was determined by calibrated AD8000 model (EC, TDS, pH meter) was measuring instrument by preparing soil water solution of 1:2.5 ratio (soil to water) following procedures or guide line given by manufacturer.

Determining of FC, PWP moisture content and bulk density: Field capacity (FC), permanent wilting point (PWP) and bulk density $\left(\rho_{b}\right)$ of the soil in the study area was determined from particle size result by using SPAW-version
6.2.0.75 software. After getting soil moisture values, water availability to crops from the soil was calculated. The total available water (TAW) in root zone is then be computed as the difference in moisture contents between field capacity (FC) and permanent wilting (PWP) as follows [14].

Crop water and irrigation water requirement: Crop coefficient $(\mathrm{Kc})$ for initial, development, mid and late stages, root depth, allowable depletion level was determined from CROPWAT data base and FAO tables [14]. Meteorological data was collected from nearest station as Erer automatic meteorological station which was situated in Babile district. The station was established in since 2015. Even though the station was high precision there was no long-term data records, and no other optional station. Therefore available data of 4 year was used to determine reference evapotranspiration (ETo).

Table 2. Average monthly climatic data of Erer Automatic recording meteorological station and reference evapotranspiration.

\begin{tabular}{|c|c|c|c|c|c|c|c|}
\hline Month & Minimum Temp $\left({ }^{\circ} \mathrm{C}\right)$ & Maximum Temp $\left({ }^{\circ} \mathrm{C}\right)$ & R. H (\%) & Wind $\left(\mathrm{km} \mathrm{day}^{-1}\right)$ & Sunshine (hr) & Ra. $\left(M^{\prime} ~ m^{-2}\right.$ day $\left.^{-1}\right)$ & ETo. $\left(\mathrm{mm} \mathrm{day}^{-1}\right)$ \\
\hline January & 7.0 & 32.1 & 51 & 111 & 8.5 & 20 & 3.75 \\
\hline February & 14.5 & 32.5 & 68 & 104 & 8.2 & 20.8 & 4.12 \\
\hline March & 15.4 & 33.6 & 63 & 112 & 7.0 & 20.1 & 4.37 \\
\hline April & 16.1 & 33.5 & 76 & 104 & 14.5 & 31.9 & 6.14 \\
\hline May & 18.7 & 29.9 & 85 & 92 & 15.4 & 32.5 & 6.04 \\
\hline June & 18.2 & 29.7 & 89 & 95 & 16.1 & 32.8 & 5.98 \\
\hline July & 16.8 & 29.8 & 97 & 92 & 18.7 & 36.8 & 6.55 \\
\hline August & 13.7 & 30.9 & 87 & 78 & 18.2 & 37.0 & 6.56 \\
\hline September & 11.0 & 32.0 & 78 & 86 & 16.8 & 35.1 & 6.17 \\
\hline October & 7.5 & 30.6 & 63 & 104 & 13.7 & 29.2 & 4.99 \\
\hline November & 13.0 & 23.9 & 49 & 95 & 11.0 & 23.7 & 4.07 \\
\hline December & 12.8 & 23.5 & 52 & 138 & 7.5 & 18.2 & 3.58 \\
\hline Average & 13.7 & 30.2 & 72 & 101 & 13 & 28.2 & 5.19 \\
\hline
\end{tabular}

RH= Relative humidity; Ra. =Radiation; ETo = Reference Evapotranspiration.

Water application and discharge measurement: Water source obtained from manual hand dug well pumped by using diesel fuel pump for irrigated vegetable production. The discharge was measured at pump delivery tube before reaching the field and it was directly measured at outlet. Smaller supply channels that were feed the furrows for furrow irrigation system and through careful opening and closure of channel banks, the water was supplied into furrows and the flow was measured by parshall flume in the field. Irrigation water was conveyed to the plots through a circular orifice and its quantity was calculated using the equation of immersed orifice as follows [15].

$$
\mathrm{Q}=0.61 \times 0.334 * \mathrm{~A} \sqrt{h}
$$

where: $\mathrm{Q}=$ Quantity of irrigation water in $1 \mathrm{sec}^{-1}, \mathrm{~A}=$ Area of the orifice in $\mathrm{cm}^{2}$ and $\mathrm{h}=$ Effective water head over the orifice center in $\mathrm{m}$.

Crop water use efficiency (CWUE) in $\mathrm{kg} \mathrm{m}^{-3}$ : It is the ratio of crop yield (Y) to the amount of water required (WR) by the crop in the process of evapo-transpiration is formulated as:

$$
\mathrm{CWUE}=\frac{\mathrm{Y}}{\mathrm{WR}}
$$

Irrigation water use efficiency (IWUE) in $\mathrm{kg} \mathrm{m}^{-3}$ : It is the ratio of crop yield (Y) to the total amount of water (TW) used in the field determined as:

$$
\mathrm{IWUE}=\frac{\mathrm{Y}}{\mathrm{TW}}
$$

Economical water productivity in $\left(\right.$ Birr $\left.\mathrm{m}^{-3}\right)$ : it is relates the economic benefits per unit of water used and calculated by:

$$
\mathrm{WP}=\frac{\text { Yield in cash in }(\text { value })}{\text { Total water consumed in }\left(m^{3}\right)}
$$

where; $\mathrm{Wp}$ is the economic water productivity in birr $\mathrm{m}^{-3}$, out-put is the product of marketable yield and market price in birr, and water consumed in $\mathrm{m}^{3}$.

Water saving was calculated by the following way [16]

$$
\text { Water saved }(\%)=\frac{\text { Water used in Every FI - Water used AFI }}{\text { Water used in EFI }}
$$

\subsection{Data Analysis}

All measured variables was subjected to analysis of variance appropriate for RCBD. Significant mean separation will be compared using least significant difference (LSD) and Duncan's Multiple Range Test (DMRT) by Genstat $15^{\text {th }}$ version software was used for analysis of variance. 


\section{Result and Discussion}

\subsection{Soil Physical Properties of Experimental Field}

Laboratory analysis result indicated that particle size distribution the study area was found as sand clay loam ' throughout the depths of $0-20 \mathrm{~cm}$ and $20-40 \mathrm{~cm}$. The average soil bulk density of $0-40 \mathrm{~cm}$ soil depth was $1.6 \mathrm{~g} \mathrm{~cm}^{-3}$. Average available soil moisture content for the top $(0-40 \mathrm{~cm})$ soil depths was observed as $15.8 \%$ in volume percent and representative value of total available water (TAW) of 142.6 $\mathrm{mm} \mathrm{m} \mathrm{m}^{-1}$ was obtained by considering the average of $0-40 \mathrm{~cm}$ soil depth. The average OM of the soil was found as $1.2 \%$. Representative value of the soil $\mathrm{pH}$ at 1:2.5 soil to water was 6.5. Field level infiltration test indicated that basic infiltration rate of the experimental area soil was $24 \mathrm{~mm} \mathrm{hr}^{-1}$ (Table 3).

Table 3. Physical properties of experimental soil.

\begin{tabular}{|c|c|c|c|c|c|c|}
\hline \multicolumn{7}{|c|}{ Averaged values of 0-20 and $20-40 \mathrm{~cm}$ depth of soil } \\
\hline & & & \multicolumn{4}{|c|}{ Particle size distribution } \\
\hline & & & Sand $(\%)$ & Silt (\%) & Clay (\%) & Textural class \\
\hline & & & 65 & 25 & 10 & Sandy clay loam \\
\hline $\mathrm{BD}\left(\mathrm{gcm}^{-3}\right)$ & FC (Vol. \%) & PWP (Vol. \%) & TAW $\left(\mathrm{mm} \mathrm{m}^{-1}\right)$ & OM (\%) & pH & Infiltration rate $\left(\mathrm{mm} \mathrm{hr}^{-1}\right)$ \\
\hline 1.6 & 24.5 & 14.3 & 142.6 & 1.2 & 6.5 & 24.0 \\
\hline
\end{tabular}

Note: $\mathrm{FC}=$ Field capacity volume base: $\mathrm{PWP}=$ Permanent wilting point volume base: $\mathrm{BD}=$ bulk density; TAW $=$ Total available water: $\mathrm{OM}=$ Organic matter: $\mathrm{pH}=$ power of Hydrogen.

\subsection{Gross Irrigation Water Applied for Each Growth Stages of Treatments}

All treatments were conducted according to the initially planned framework and followed the required amount of gross water applied for each stages. Comparison of two irrigation methods (IMs); alternating furrow irrigation (AFI) and every furrow irrigation (EFI) under three irrigation intervals (IIs): (4, 6 and 8 day) as described in Table 4.
From practical point of view for alternate furrow irrigation (AFI) method, water applied only two or three furrow at each successive irrigation event if the plot have five irrigation furrow $o$, so water saved from these irrigation method was greater than EFI for each event throughout growth season, even though, the yield obtained was less than full or every furrow irrigated once per predetermined irrigation interval.

Table 4. Water applied per growth stage and water saved from each treatments.

\begin{tabular}{lllllll}
\hline \multirow{2}{*}{ Treatments } & \multicolumn{3}{l}{ Irrigation water in $(\mathbf{m m})$ per each growth stage } & \multirow{2}{*}{ I } & \multirow{2}{*}{ (moss) } & Water saved in (\%) \\
\cline { 2 - 5 } & Initial & Development & Mid & Late & 321.6 & 58 \\
AFI with 8 day & 33.1 & 45.3 & 64.6 & 49.9 & 428.8 & 44 \\
AFI with 6 day & 44.2 & 60.4 & 86.2 & 66.5 & 643.2 & 16 \\
AFI with 4 day & 66.3 & 90.6 & 129.3 & 99.8 & 382.8 & 50 \\
EFI with 8 day & 39.5 & 53.9 & 76.9 & 59.4 & 510.4 & 33 \\
EFI with 6 day & 52.6 & 71.9 & 102.6 & 79.2 & 765.7 & 0 \\
EFI with 4 day & 78.9 & 107.8 & 153.9 & 118.8 & 3052.5 & \\
Total & 314.6 & 429.8 & 613.6 & 473.6 & & \\
\hline
\end{tabular}

\subsection{Effect of IMs and IIs on Growth Yield Components and Water Productivity}

Effect of IMs and IIs on plant height: ANOVA shows that plant height at harvest maturity was significantly $(\mathrm{P}<0.05)$ influenced by irrigation methods, and IIs had highly significantly $(\mathrm{P}<0.01)$ effect during both planting seasons The highest mean plant height of both planting seasons 72.9 $\mathrm{cm}$ and $76.8 \mathrm{~cm}$ was recorded by EFI and every 4 day II respectively. Whereas the lowest mean plant height was observed at every 8 day water application interval as $64.2 \mathrm{~cm}$ in second year planting season which was not significant different from 6 day irrigation frequency (Table 5).

Effect of IMs and IIs on number of fruit per plant (NFPP): Number of fruit per plant was counted at fruit set stage or one week after flower drop of the crop. Statistical analysis indicates that NFPP was highly significantly $(\mathrm{p}<0.01)$ affected by IIs. But IMs had significant $(p<0.05)$ effect on NFPP recorded during both planting seasons. The highest mean NFPP owned by EFI as 86.3 was observed in both planting season, whereas 96.9 and 91.8 NFPP was produced by every 4 day water application interval in first and second planting season respectively. The lowest mean NFPP produced as 70.9 and 63.4 were recorded by ever 8 day IIs as shown in Table 5. The result agreed with [20] reported that FI treatments gave the highest yield, plant diameter and number of leaves of tomato crop when compared with other treatments. In contrast of this study results, [21] reported that different irrigation levels did not significantly affect mean leaf number and plant diameter.

Effect of IMs and IIs on tomato yield: Analysis of variance indicated that total yield was significantly $(\mathrm{P}<0.05)$ influenced 
by furrow IMs in both planting season, whereas, IIs had highly significant $(p<0.01)$ effect on yield. The highest mean total yield was recorded by EFI as 33.2 and $37.2 \mathrm{t} \mathrm{ha}^{-1}$ in respective planting season, while the lowest mean total yield of $31.5 \mathrm{t} \mathrm{ha}^{-1}$ was recorded by AFI, during first year (Table 5). Accordingly the result under different water application frequency lied in between $39.6 \mathrm{t} \mathrm{ha}^{-1}$ and $24.8 \mathrm{t} \mathrm{ha}^{-1}$ in increasing order from every 4 to 8 days II respectively.

Effect of IMs and IIs on water productivity and yield reduction: The result indicated that water saved from treatment combination of AFI with 4,6 and 8 days water application were $16 \%, 44 \%$ and $58 \%$ of total volume of irrigation water applied. Whereas EFI with 6 and 8 day application obtained $33.3 \%$ and $50 \%$ respectively.

Table 5. Effect of IMs and IIs on growth and yield components of tomato.

\begin{tabular}{|c|c|c|c|c|c|c|c|}
\hline \multirow{3}{*}{ Treatment } & & \multicolumn{6}{|c|}{ Two year data of crop growth and yield component } \\
\hline & & \multicolumn{3}{|c|}{$2017 / 18$} & \multicolumn{3}{|c|}{ 2018/19 } \\
\hline & & PH & NFPP & TY & PH & NFPP & TY \\
\hline \multirow{3}{*}{ Irrigation method (IMs) } & EFI & 72.9 & 86.3 & 33.3 & 70.7 & 83.4 & 37.2 \\
\hline & AFI & 70.0 & 80.8 & 31.5 & 67.5 & 73.6 & 34.9 \\
\hline & LSD & 2.2 & 4.9 & 1.4 & 3.0 & 5.9 & 2.0 \\
\hline \multirow{3}{*}{ Irrigation intervals (IIs) } & 4 day & $77.0^{\mathrm{a}}$ & $96.9^{\mathrm{a}}$ & $39.6^{\mathrm{a}}$ & $76.5^{\mathrm{a}}$ & $91.8^{\mathrm{a}}$ & $39.2^{\mathrm{a}}$ \\
\hline & 6 day & $70.6^{\mathrm{b}}$ & $82.6^{\mathrm{b}}$ & $33.1^{\mathrm{b}}$ & $66.4^{\mathrm{b}}$ & $80.3^{\mathrm{b}}$ & $35.3^{\mathrm{b}}$ \\
\hline & LSD & 2.7 & 6.0 & 1.7 & 3.7 & 7.3 & 2.5 \\
\hline
\end{tabular}

PH-Plant height (cm): NFPP- Number of fruit per plant in (No..): TY-Total yield in (ton ha ${ }^{-1}$ ) and, Note: mean followed by the same letter in the columns are not significantly different.

Table 6. Average water saved and relative yield reduction of season.

\begin{tabular}{|c|c|c|c|c|c|c|}
\hline Treatments & $I_{\text {gross }}\left(\mathrm{m}^{3}\right)$ & Water saved $\left(\mathrm{m}^{3}\right)$ & Water saved (\%) & Yield $\left(\mathrm{kg} \mathrm{ha}^{-1}\right)$ & Yield reduced $\left(\mathrm{kg} \mathrm{ha}^{-1}\right)$ & Yield reduced $(\%)$ \\
\hline AFI with 8 day & 3215.8 & 4440.9 & 58.0 & 27341.5 & 2006.5 & 32.3 \\
\hline AFI with 6 day & 4287.7 & 3369.0 & 44.0 & 34040.0 & 6358.4 & 15.7 \\
\hline AFI with 4 day & 6431.6 & 1225.1 & 16.0 & 38391.9 & 13056.9 & 4.9 \\
\hline EFI with 4 day & 7656.7 & 0.0 & 0.0 & 40398.4 & 0.0 & 0.0 \\
\hline EFI with 6 day & 5104.4 & 2552.3 & 33.3 & 34498.1 & 5900.3 & 14.6 \\
\hline EFI with 8 day & 3828.3 & 3828.4 & 50.0 & 30625.8 & 9772.6 & 24.2 \\
\hline
\end{tabular}

EFI with 4 day water application produced maximum yield because this treatment received maximum amount of water of all treatment, as a result no yield reduction observe or it used as control for comparison purpose. Whereas AFI with 4 day II shows little yield reduction which was indicated as $4.97 \%$, as compared with no stressed (EFI with the same II). But AFI with 4 day II was saves $16 \%$ water from gross water applied when compared with no stressed treatment EFI with 4 day (Table 6).

Similarly treatment with 6 day II of AFI and, EFI were indicated that significant yield reduction as $15.7 \%$ and $14.6 \%$ respectively. But total gross volume of irrigation water saved as 44 and $33.3 \%$ for AFI and EFI of the same II treatment (Table 6). Hence water saved from AFI and EFI with 6 day II could irrigate more or additional cultivation land at water limited or scarce environment. Accordingly [25] concluded that water saved through improved irrigation systems could allow for an expansion of cultivation land and increase crop production in water limited area. Farmers' decisions are often driven by maximizing their return and rarely by environmental concerns; if they pursue efforts to save water, do they often use it to expand their irrigated areas or shift to higher value crops, rather than losing water allocation.

Table 7. Effect of furrow IMs and IIs on physical water productivity.

\begin{tabular}{|c|c|c|c|c|c|c|c|}
\hline \multirow{3}{*}{ Treatment } & & \multicolumn{6}{|c|}{ Two year data of crop water productivity } \\
\hline & & \multicolumn{3}{|c|}{$2017 / 18$} & \multicolumn{3}{|l|}{ 2018/19 } \\
\hline & & CWUE & IWUE & EWP & CWUE & IWUE & EWP \\
\hline \multirow{3}{*}{$\begin{array}{l}\text { Irrigation methods } \\
\text { (IMs) }\end{array}$} & EFI & 10.3 & 6.2 & 49.7 & 7.9 & 4.8 & 38.3 \\
\hline & AFI & 11.6 & 6.9 & 55.5 & 8.9 & 5.3 & 42.6 \\
\hline & LSD & 0.59 & 0.36 & 2.87 & 0.42 & 0.25 & 1.99 \\
\hline \multirow{3}{*}{$\begin{array}{l}\text { Irrigation intervals } \\
\text { (IIs) }\end{array}$} & Every 4 & $9.4^{\mathrm{b}}$ & $5.6^{\mathrm{b}}$ & $45.2^{\mathrm{b}}$ & $6.2^{\mathrm{c}}$ & $3.7^{\mathrm{c}}$ & $29.9^{c}$ \\
\hline & Every 6 & $11.8^{\mathrm{a}}$ & $7.1^{\mathrm{a}}$ & $56.8^{\mathrm{a}}$ & $8.4^{\mathrm{b}}$ & $5.1^{\mathrm{b}}$ & $40.3^{b}$ \\
\hline & LSD & 0.73 & 0.44 & 3.51 & 0.51 & 0.31 & 2.45 \\
\hline
\end{tabular}

$(\mathrm{CWUE})=$ Crop water use efficiency in $\mathrm{kg} \mathrm{m}^{-3}$ : IWUE $=$ Irrigation water use efficiency in $\mathrm{kg} \mathrm{m}^{-3}$ : EWP $=$ Economic water productivity in Birr $\mathrm{m}^{-3}$.

Crop water use efficiency (CWUE): Statistical analysis (ANOVA) indicated that CWUE was highly significantly $(\mathrm{P}<0.01)$ influenced by both IMs and IIs. The highest of 11.6 $\mathrm{kg} \mathrm{m}^{-3}$ and the lowest $7.9 \mathrm{~kg} \mathrm{~m}^{-3}$ was produced by AFI and
EFI respectively from both planting season. Whereas CWUE, application frequency, was significantly increases when irrigation days or intervals decreased. Hence the result shows that, the highest CWUE $11.9 \mathrm{~kg} \mathrm{~m}^{-3}$ was obtained from 6 day 
water application intervals followed by 8 day as $11.6 \mathrm{~kg} \mathrm{~m}^{-3}$, but statistically had not significant difference, and the lowest $9.4 \mathrm{~kg} \mathrm{~m}^{-3}$ was recorded at 4 day water application interval correspondingly (Table 7) in first year planting. Similarly the highest and lowest mean value 10.7 and $6.2 \mathrm{~kg} \mathrm{~m}^{-3}$ CWUE was recorded in second year respectively. It is also evident that, at each irrigation methods, the CWUE increased with increasing water application day i.e. 4 to 8 day.

Effect of furrow IMs and IIs on Irrigation water use efficiency (IWUE): The analysis of variance, showed that IWUE was highly significantly $(\mathrm{P}<0.01)$ influenced by both furrow IMs and IIs. The result revealed that IWUE was significantly increased from 4.8 to $6.9 \mathrm{~kg} \mathrm{~m}^{-3}$, of EFI and AFI respectively that computed for both cropping season. Similarly the highest mean IWUE of $7.1 \mathrm{~kg} \mathrm{~m}^{-3}$ and the lowest as $3.7 \mathrm{~kg} \mathrm{~m}^{-3}$ was recorded by 6 day 4 day water application interval respectively during both planting season (Table 7). This result was agreed with [27]; report on wheat, the result reveals that WUE values was improved under AFI as compared with the EFI method. [17] For field grown potato showed that compared with FI (full irrigation), PRD (partial root drying) treatment saved $30 \%$ of water and increased water use efficiency. Moreover [28] reported that both $\mathrm{AFI}_{7}$ and $\mathrm{AFI}_{14}$ achieved high WUE of maize was obtained as compared with EFI.

Effect of furrow IMs and IIs on Economic water productivity (EWP): The analysis of variance revealed that economic water productivity was highly significantly $(\mathrm{P}<0.01)$ influenced by both IMs and IIs. The result indicates that mean maximum economic water productivity value for AFI obtained as 55.5 ETB $\mathrm{m}^{-3}$, which had significant different from EFI and the mean minimum EWP was recorded by EFI as $38.4 \mathrm{ETB}^{-3}$ for both planting season (Table 7). Accordingly, EWP was significantly influenced by different irrigation interval, the result showed that maximum value $56.8 \mathrm{ETB} \mathrm{m}^{-3}$ by every 6 day crop water application which was not significantly different from 8 day and the lowest by 4 day irrigation interval was recorded during first year cropping season. Whereas the second year data indicates that maximum EWP was obtained from 8 day II as 51.1 ETB $\mathrm{m}^{-3}$ followed by 6 day and the lowest as $29.9 \mathrm{ETB} \mathrm{m}^{-3}$ as described in the (Table 7). This result reveals that, economic water productivity depends on the ratio of yield obtained in cash to the amount and frequency of water applied in volume $\left(\mathrm{m}^{-3}\right)$ basis. Hence every 8 day irrigation interval had least water application frequency and similarly the yield was relatively lower when compared with 6 and 4 day water application interval, this resulted in superior economic water productivity.

\section{Discussion}

\subsection{Gross Irrigation Water Applied for Each Growth Stages of Treatments}

Hence the result indicated that water saved from treatment combination of AFI with 4, 6 and 8 day IIs were found as
$16 \%, 44 \%$ and $58 \%$ of total volume of irrigation water applied. Whereas water saved from EFI with every 6 and 8 application days were $33 \%$ and 50\% respectively (Table 4). According to [17] comparative report of FI (full irrigation) with PRD (partial root drying) for field grown potato shows, PRD treatments were saves' $30 \%$ of water which increases water use efficiency of the crop.

\subsection{Effect of IMs and IIs on Growth, Yield Components and Water Productivity}

Effect of IMs and IIs on plant height: The result indicates furrow water application methods and intervals had significant effect on plant height. Hence, this finding confirms plant height increased as frequency of application decreases from 8 to 4 day and the result was agreed with [18] reports; the finding confirmed, shoot and pod biomass was significantly decreased in both PRD (partial root drying) and DI (deficit irrigation) as compared with FI of beans. Similarly [19] reported that, leaf area increment, for averaged to single leaf, showed that CFI produced significantly larger leaves than that of AFI and FFI in the early growth stage cotton.

Effect of IMs and IIs on number of fruit per plant (NFPP): The result shows that water application days or intervals have remarkable effect on tomato yield. This may due to aridity of environment, which increases evapotranspiration of crop as the length of irrigation intervals wide ( 4 to 6 to 8 days) or vice versa. Similar results was reported by [22], the fining indicated that average of two seasons yield of maize irrigated under fixed furrow (FFI) and every furrow (EFI) irrigation method with every 7 day irrigated treatments were higher than that obtained from FFI every 14 days. According to [23], 7 day irrigation frequency or interval using fixed-furrow irrigation produce higher grain yield than less frequent irrigation interval (every 14 day). [24] Explored that tomato plants grown under PRD had shown $26 \%, 10 \%$ and $30 \%$ reduction in height, number of leaves and number of fruits respectively.

The result revealed that tomato performance under different irrigation method with irrigation intervals; as frequency of water application increases from 4 to 8 , the yield reduction was also increase. From different point of view the optimum yield reduction is not more than $15 \%$. In this view better result lies under AFI with 4 and 6 day and EFI with 6 day II. This result agreed with [26] finding; concluded that improper irrigation depth and frequency can substantially reduce yields by increasing the proportion of rough, deformed tubers.

Comparing the results of the irrigation method with its intervals in view of water productivity (WUE and EWP), it clearly confirmed that, AFI had significant advantage over EFI within acceptable yield reduction range. Generally from the result of crop water productivity (CWUE, IWUE and EWP), clearly approves that, AFI had beneficial advantage over EFI on water saving and the same consequent happened for irrigation interval i.e. increasing irrigation from 4 day followed by 6 to 8 days increases water use efficiency of crop. 
Hence the result indicates that interaction effect of factors (IMs and IIs) saves significant amount of water. Hence, it could increasing addition irrigable land and/or improve minimize operation or variable cost. The same idea reported by some authors, according to [29], water productivity, is considerably increased by using APRD (alternative partial root drying) on different crops. [30] Also reported that PRD significantly reduced yield by $24 \%$, while WP (water productivity) increased by $52 \%$ compared with the FI (full irrigation).

\section{Conclusion}

Experiment was conducted at Eastern Ethiopia of Harari Regional State of Erer Woldiya district, on farm field for two years. The purpose of this study was to evaluate the effect of AFI and EFI with different irrigation intervals on growth component, yield and water use efficiency of tomato. Accordingly the parameters for experimentation include growth component: such as plant height and number fruit per plant and yield parameter total fruit yield and, water productivities.

Plant height at harvest maturity was significantly $(\mathrm{P}<0.05)$ influenced by IMs, but IIs had shown highly significantly $(\mathrm{P}<0.01)$ effect on plant height on both planting season. Statistical analysis indicates that NFPP was highly significantly $(\mathrm{p}<0.01)$ affected by IIs. But NFPP was significantly affected $(p<0.05)$ by irrigation methods at both planting seasons. Total fruit yield was significantly influenced $(\mathrm{P}<0.05)$ by furrow irrigation methods in both planting season, but the effect of water application days were highly significant $(\mathrm{p}<0.01)$.

Generally crop water productivity (CWUE, IWUE and EWP) revealed that, alternate furrow irrigation had beneficial advantage over every furrow irrigation on water saving and the same consequent perceived for irrigation interval i.e. increasing irrigation interval from 4 day followed by 6 to 8 days increases water use efficiency of crop. Hence the result indicates that interaction effect of (IMs and IIs) save significant amount of water. Hence water saved from treatment combination of AFI with 4, 6 and 8 IIs were $16 \%, 44 \%$ and $58 \%$ of total gross volume of irrigation water applied respectively. While EFI with 6 and 8 application day obtained $33 \%$ and $50 \%$. Therefore amount of saved water from each treatment have advantage of increasing addition land, time or labor productivity. AFI with 4 day II shows little yield reduction which was indicated as $4.9 \%$, as compared with no stressed (EFI with the same II). Accordingly AFI and, EFI were shows significant yield reduction as $15.7 \%$ and $14.6 \%$ respectively. But total amount of gross volume of irrigation water saved as $44 \%$ and $33.3 \%$ for AFI and EFI of the same IIs treatment.

\section{Recommendation}

The finding approves that farmers can practice AFI with 4 day II, as first option, it was identified as negligible yield reduction of less than $5 \%$ as compared to every furrow irrigation with the same II. Another alternative EFI and AFI with 6 day IIs was observed as a second option, if they pursue efforts to save water, do farmers often use it to expand their irrigated areas or shift to higher value crops. Finally all possible efforts could be made to introduce the technologies to the farming community since the use of furrow irrigation method with best fit IIs to save or sustain irrigated agriculture for next generation.

\section{References}

[1] Ghrab M, Gargouri K, Bentaher H, Chartzoulakis K, Ayadi M, Ben Mimoun M, Masmoudi MM, Ben Mechlia N, Psarras G (2013) Water relations and yield of olive tree (cv. Chemlali) in response to partial root-zone drying (PRD) irrigation technique and salinity.

[2] Chai Q, Gan Y, Turner NC, Zhang RZ, Yang C, Niu Y, Siddique KHM (2014a) Water-saving innovations in Chinese agriculture. Adv Agron 126: 147-197. doi: 10.1016/B978-012-800132-5.00002-X.

[3] Forouzani M, Karami E (2011). Agricultural water poverty index and sustainability. Agron Sustain Dev 31: 415-432. doi: 10.1051/agro/ 2010026.

[4] Bhangar, M. I., Saima, Q. M., 2008. Water research activities in Pakistan. In: Proceedings of the 1st Technical Meeting of Muslim Water Researchers Cooperation (MUWAREC), December, p. 82.

[5] Burt, C. M., Clemmens, A. J., Strelkoff, T. S., Solomon, K. H., Bliesner, R. D., Hardy, L. A., Howell, T. A., Eisenhauer, D. E., 1997. Irrigation performance measures: efficiency and uniformity. J. Irrig. Drain. Eng. 123, 423-442.

[6] Siyal A. A., Mashori A. S, Bristow, K. L., Van Genuchten M. Th. 2016. Alternate furrow irrigation can radically improve water productivity of okra. Agricultural Water Management. Journal homepage: www.elsevier.com/locate/agwat

[7] Mashori, A. S., 2013. Evaluation of the performance of the alternate furrow irrigation under climatic conditions of Sindh. In: M. E. Thesis. Sindh Agriculture University, Tandojam, Pakistan.

[8] Nasri, M., M. Khalatbari, and H. A. Farahani. 2010. The effect of alternate furrow irrigation under different nutritional element supplies on some agronomic traits and seed qualitative parameters in corn (Zea mays L.) Journal of Cereals and Oilseed 1 (2): 17-23.

[9] Kashiani, P., G. Saleh, M. Osman, and D. Habibi. 2011. Sweet corn yield response to alternate furrow irrigation methods under different planting densities in a semi-arid climatic condition. African Journal of Agricultural Research 6: 1032104005 .

[10] Jema Haji, Yared Mengesha, Demeksa Tamiru, Getnet Alemu, Gulilat Birhane, Tamene Chaka 2010. Research-inspired Policy and Practice Learning in Ethiopia and the Nile region (RiPPLE) Aid effectiveness in the WASH (Water Sanitation and Hygiene) sector in Oromia region, Eastern Hararghe zone: The case of Goro-Gutu and Babile woreda. 
[11] AGP-II (Agricultural Growth Program). 2016. A participatory agricultural production systems analysis of AGP-II districts: the case of Dire Dawa Administrative Council and Harari Region, Eastern Ethiopia, implications for research and development. Unpublished report by Alemayehu B., Kibret Ketema K., Meles F., Lelisa O., Abdulahi U.: Fedis Agricultural Research Center Harar; Ethiopoia.

[12] Staney, W. E and B. yerima. 1992. Improvement of Soil Science for Agriculture Development: Guideline for sampling and fertility evaluation. Ministry of Natural Resource Development and Environmental Pollution, Addis Ababa, Ethiopia.

[13] Walker, A. and I. A. Black. 1934. An Examination of Different Method for Determining Soil Organic Matter and a Proposed Modification of the Chromic Acid Titration Method. Soil Sci. 37: 29-37.

[14] A. A. Abd El-Halim. 2015. Water saving under fixed-furrow surface irrigation in clay soil of the Middle Nile Delta of Egypt. www.witpress.com, ISSN 1743-3541 (on-line) WIT Transactions on Ecology and The Environment, Vol 200, C 2015 WIT Press Water and Society III 343 doi: $10.2495 / \mathrm{WS} 150291$.

[15] James, L. G. (1988). Principles of Farm Irrigation System Design. John Wiley. \& sons, New york Chichester Brisbane Toronto Singapore, $410 \mathrm{p}$.

[16] Chapagain T, Yamaji E. 2010. The effects of irrigation method, age of seedling and spacing on crop performance, productivity and water-wise rice production in Japan. Paddy Water Environment, 8, 81-90.

[17] Shahnazari, A., F. Liu, M. N. Andersen, S. E. Jacobsen, C. R. Jensen. 2007. Effects of partial root zone drying on yield, tuber size and water use efficiency in potato under field conditions. Field Crop Res. 100, 117-124.

[18] Wakrim, R., Wahbi, S., Tahi, H., Aganchich, B., Serraj, R., 2005. Comparative effects of partial root drying (PRD) and regulated deficit irrigation (RDI) on water relations and water use efficiency in common bean (Phaseolus vulgaris L.). Agriculture, Ecosystems \& Environment, 106: 275-287.

[19] Li-Song Tang, Yan Li Jianhua Zhang, 2005. Physiological and yield responses of cotton under partial root zone irrigation. www.elsevier.com/locate/fcr/doi:10.1016/j.fcr.2005.01.0

[20] Kamel N, E. Fathia, M. Mohamed, Netij Ben. 2013. Soil salinity, yield and water productivity of lettuce under irrigation regimes with saline water in arid conditions of Tunisia. International journal of Agronomy and Plant Production. Vol., 4 (5), 892-900.
[21] Acar B, M. Paksoy, O. Türkmen, M. Seym, 2008. Irrigation and nitrogen level affect lettuce yield in greenhouse condition. African Journal of Biotechnology 7 (24): 4450-4453.

[22] El-Halim Abd A. A., 2015. Water saving under fixed-furrow surface irrigation in clay soil of the Middle Nile Delta of Egypt. (On-line); www.witpress.com, WIT Transactions on Ecology and the Environment, Vol. 200.

[23] Ibrahim, S. A. \& Kandil, H., 2007. Growth, Yield and Chemical Constituents of Corn (Zea Maize L.) As Affected by Nitrogen and Phosphors Fertilization under Different Irrigation Intervals. J Appl Sci Res, 3, pp. 1112-1120.

[24] Stickic R, P. S. (2003). Partial Root Drying-A new Technique for growing plants that saves water and improves quality of fruit. Bulgarian.

[25] Pfeiffer L. and Y. C. Lin. 2014. Does efficient irrigation technology lead to reduced groundwater extraction? Empirical evidence, J. Environ. Econ. Manag. 67, 189 208, doi: 10.1016/j.jeem.2013.12.002, 3596, 3615 Journal of Plant Physiology, special issue; $164-171$.

[26] Shock CC, Pereira A, Wang FX, Flock R, Eldredge E (2013) Successful irrigation scheduling of potato. Sustainable Agriculture Techniques. Oregon State University, USA. pp. $1-8$.

[27] Abdel-Maksoud, H. H., Sanaa A. Othman, and A. Y. El-Tawil. 2002. Improving water and N-use utilization for feld crops via alternate furrow irrigation technique 1-Maize crop. Mansoura University Journal of Agricultural Sciences Mansoura University 27: 8761- 8769.

[28] Awad Abd El-Halim. 2013. Impact of alternate furrow irrigation with different irrigation intervals on yield, water use efficiency, and economic return of corn. Chilean Journal of Agricultural Research 73 (2) April-June 2013. Tanta University, Faculty of Agriculture, Tanta, Egypt.

[29] Ahmadi, S. H., M. N, Andersen, F., Plauborg, R. T., Poulsen, C. R., A. R., Jensen, Sepaskhah, S., Hansen, 2010b. Effects of irrigation strategies and soils on field grown potatoes: Yield and Water Productivity. Agricultural Water Management. DOI 10.1 016/j.agwat.2010.07.007.

[30] Guang-Cheng, S., Zhan-Yua, Z., Nac, L., Shuang-Ena, Y., Weng-Ganga, X., 2008. Comparative effects of deficit irrigation (DI) and partial root zone drying (PRD) on soil water distribution, water use, growth and yield in greenhouse grown hot pepper. Scientia Horticulturae, 119: 11-16. 